8. Rassoulzadegan M, Naghashfar Z, Cowie A, et al. Expression of individual polyoma virus early proteins in oncogenic transformation. Proc Natl Acad Sci USA 1983: 80 4354-8.

9. Land H, Parada LF, Weinberg RA Tumorigenic conversion of primary embryo fibroblasts requires at least two cooperating oncogenes. Nature 1983; 304: 596-602.

10. Evrard C, Galiana E, Rouget P. Establishment of " normal " nervous cell lines after transfer of polyoma virus and adenovirus early genes into murine brain cells. EMBOJ 1986 ; 5: 3157-62.

11. Évrard C, Galiana E, Rouget P. Immortalization of bipotential glial progenitors and generation of permanent "bluel " cell lines. $J$ Neurosci Res 1988 ; 21 : 80-7.

12. Évrard C, Borde I, Marin P, et al. Immortalization of bipotential and plastic glioneuronal precursor cells. Proc Natl Acad Si USA $1990 ; 87: 3062-6$

13. Bartlett PF, Reid HH, Bailey KA, Bernard $\mathrm{O}$. Immortalization of mouse neural precursor cells by c-myc oncogene. Proc Natl Acad Sci USA 1988 ; 85 : 3255-9.

14. Frederiksen K, Jat PS, Valtz N, Levy
D, McKay R. Immortalization of precursor cells from the mammalian CNS. Neuron $1988 ; 1: 439-48$.

15. Galiana E, Borde I, Marin P, et al. Establishment of permanent astroglial cell lines, able to differentiate in vitro, from transgenic mice carrying the polyoma virus large $T$ gene an alternative approach to brain cell immortalization. J Neurosci Res $1990 ; 27$ : 269-77. 16. Hammang JP, Baetge EE, Behringer RR, Brinster RL, Palmiter RD, Messing A Immortalized retinal neurons derived from SV40 T-antigen-induced tumors in transgenic mice. Neuron 1990; 4 : 775-82.

17. Mellon PL, Windle JJ, Goldsmith PC, Padula CA, Roberts JL, Weiner RI. Immortalization of hypothalamic GnRH neurons by genetically targeted tumorigenesis. Neuron $1990 ; 5: 1-10$

18. Raff MC, Miller RH, Noble M. A glial progenitor cell that develops in vitro into an astrocyte or an oligodendrocyte depending on culture medium. Nature 1983 ; 303 : 390-6. 19. Eisenbarth GS, Walsh FS, Nirenberg M. Monoclonal antibody to a plasma membrane antigen of neurons. Proc Natl Acad Sci USA 1979 ; 76 : 4913-7.
20. Horellou P, Brundin P, Kalen P, Mallet J, Björklund A. In vivo release of DOPA and dopamine from genetically engineered cells grafted to the denervated rat striatum. Neuron 1990 ; 5 : 393-402.

21. Price J, Turner D, Cepko C. Lineage analysis in the vertebrate nervous system by retrovirus-mediated gene transfer. Proc Natl Acad Sci USA 1987 ; 84: 156-60.

22. Kalderon D, Roberts BL, Richardson WD, Smith AE, A short amino acid sequence able to specify nuclear location. Cell 1984; 39 : 499-509.

23. Bonnerot C, Rocancourt D, Briand P, Grimber G, Nicolas JF. A $\beta$-galactosidase hybrid protein targeted to nuclei as a marker for developmental studies. Proc Natl Acad Sci USA 1987; 84 : 6795-9.

24. Galileo DS, Gray GE, Owens GC, Majors J, Sanes JR. Neurons and glia arise from a common progenitor in chicken optic tectum : demonstration with two retroviruses and cell type-specific antibodies. Proc Nall Acad Sci USA 1990; 87 : 458-62.

25. Capecchi MR. Altering the genome by homologous recombination. Science 1989 ; 244: 1288-92.

\title{
Immortalisation de cellules germinales mâles de souris transgéniques par l'antigène grand $T$ du virus polyome
}

\author{
M. Rassoulzadegan, V. Paquis, F. Vidal, R. Loubière, F. Cuzin \\ TEXTE NON REÇU
}

\section{Résumé}

Une série de 44 familles transgéniques a été obtenue après microinjection du plasmide pPyLT1, codant pour la protéine grand $\mathrm{T}$ du virus polyome. Les mâles de toutes les familles expriment l'ARN viral et l'antigène $T$ dans les testicules. L'hybridation in situ localise l'expression du transgène à l'intérieur des tubes séminifères, dans les zones

M. Rassoulzadegan, V. Paquis, F. Vidal, R. Loubière, F. Cuzin : Inserm U. 273, Nice, France. pré et post-méiotiques. Ces mâles demeurent asymptomatiques pendant la plus grande partie de leur vie, mais tous sans exception, entre 15 mois et deux ans, développent une forme unique de cancer bilatéral des testicules. Le tableau pathologique ne correspond pas à l'un des cancers classiques de ces organes (lymphome, séminome, carcinome embryonnaire, etc.). Ces cellules se divisent efficacement en culture, mais elles ne sont pas transplantables dans l'animal. Maintenues en croissance, elles montrent une morphologie homogène sans différenciation évidente. Dans des conditions défavorables pour la croissance (maintien prolongé à confluence, carence en sérum), on note l'apparition de deux types morphologiques distincts, des cellules de grande taille avec des noyaux lobés caractéristiques et, associées à celles-ci, des petites cellules à noyaux extrêmement compacts. Ces deux morphologies évoquent, respectivement, des cellules de Sertoli et des spermatides. Nous cherchons actuellement à optimaliser les conditions de culture pour cette différenciation et à la caractériser au niveau moléculaire (expression de gènes spécifiques de la lignée germinale mâle). 